\title{
Relationship between Understory Light and Growth of Forest-grown American Ginseng (Panax quinquefolius L.)
}

\author{
Anick R. Fournier and André Gosselin \\ Horticultural Research Center, Envirotron Building, Laval University, Ste-Foy, Que., G1K 7P4, Canada \\ John T.A. Proctor \\ Department of Plant Agriculture, University of Guelph, Guelph, Ont., N1G 2W1, Canada
}

Louis Gauthier

Les Fraises de l'Île d'Orléans Inc., Île d'Orléans, Que., G0A 3Z0, Canada

Shahrokh Khanizadeh

Agriculture and Agri-Food Canada, Horticultural Research Center, St-Jean-sur-Richelieu, Que., J3B

3E6, Canada

\begin{abstract}
Martine Dorais ${ }^{1}$
Agriculture and Agri-Food Canada, Horticultural Research Center, Envirotron Building, Laval University, Ste-Foy, Que., G1K 7P4, Canada
\end{abstract}

AdDITIONAL INDEX wORDS. Panax quinquefolius, american ginseng, hemispherical photography, light quality, sunfleck durations

\begin{abstract}
Aвstract. Our objective was to determine the relationship between daily and seasonal changes in understory light, and growth of 1- and 2-year-old american ginseng plants cultivated in a broadleaf forest. Using hemispherical photography and spectroradiometry, understory light [total, direct, and diffuse photon flux density (PFD), and sunfleck durations] and light quality [ultraviolet (UV) and red to far red (R:FR)] were evaluated during two consecutive growing seasons. While shoot and root dry weight (DW), and taproot area of 1-year-old american ginseng plants were related to sunfleck durations, accounting for up to $56 \%$ of the variation, the relationship reached a plateau at $2 \mathrm{~h}^{-\mathrm{d}^{-1}}$ sunfleck durations for growth. In September, growth of 1 - and 2 -year-old plants exposed to $<2 \mathbf{h}^{-1} \mathbf{d}^{-1}$ sunfleck durations was positively related to diffuse PFD (and total PFD for 1-year-old plants), accounting for up to $69 \%$ of the variation. In mid-season (July 2000), shoot and root growth, and leaflet area of 2-year-old american ginseng were correlated with light PFD and light quality (UV and R:FR), accounting for up to $88 \%$ of the variation. Generally, the results suggest that exposing 1- and

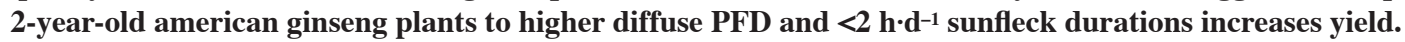

Indigenous to North American forest understories (Anderson et al., 1993), american ginseng (Panax quinquefolius L.) is a perennial shade plant highly valued for its medicinal properties attributed to the presence of ginsenosides (Briskin, 2000; Fournier et al., 2003). The almost complete decimation of american ginseng populations due to the destruction of its habitat and overexploitation (Charron and Gagnon, 1991) has rendered its cultivation, under artificial shade and increasingly in forests (Persons, 1995), essential for commercial exploitation. Forest-grown ginseng experiences a dynamic light environment during a growing season due to the development of the forest canopy and the presence of gaps permitting direct sunlight to reach the understory (sunflecks). In May, american ginseng growing in Southern Quebec, Canada, is exposed to high light levels since the initial development of the forest canopy coincides with its emergence. At this time, ginseng plants have rapid shoot growth (leaf and stem) and fully developed shoots are obtained in $\approx 1$ month (Proctor and Bailey, 1987).

Received for publication 20 June 2003. Accepted for publication 22 Oct. 2003. The authors wish to thank Claudine Ménard, Daniel Mailly, and Denis Robitaille for their considerable technical assistance. Financial support was provided by Agriculture and Agri-Food Canada, Les Fraises de l'Île d'Orléans, and the Horticultural Research Center of Laval University.

1To whom reprint requests should be addressed; e-mail doraisma@agr.gc.ca.
American ginseng seeds produce a single trifoliate leaf after a chilling period and a new leaf is usually added during subsequent growth years with up to five or six leaves. During a growing season, only one set of leaves is produced and root growth depends solely on these leaves (Parmenter and Littlejohn, 2000). For 2- to 5 -year-old plants, shoot growth results in a $30 \%$ to $50 \%$ decrease in root dry weight (DW) early in the growing season because stored resources are used to produce leaves. Actual root weight gains occur from June to September (Proctor et al., 1998) after leaves become carbohydrate sources instead of sinks. Generally, roots are harvested after 3 or 4 years of growth when cultivated under artificial shade (Court et al., 1996), while those grown under forest conditions can take up to 8 years before achieving commercially valuable root sizes (Hsu, 2002). However, roots issued from forest cultivation are deemed more valuable since they contain higher levels of ginsenosides and resemble wild roots (Betz et al., 1984; Hsu, 2002). Even if fibrous roots contain higher levels of ginsenosides than taproots, the commercially-valuable section of root organs are taproots (Betz et al., 1984).

Once the development of the forest canopy is complete from end of May to late June (Anderson et al., 1993), understory plants are generally exposed to moderate light intensities, although they remain exposed to sunflecks. Depending on their duration and periodicity, sunflecks can be sources of excessive light which af- 
fect the physiology of various shade plants (Königer et al., 1995; Kursar and Coley, 1999). To date, only a few authors explored the effect of understory light on growth of ginseng plants (Wang et al., 1995) and they showed that asian ginseng (Panax ginseng C.A. Meyer) has the highest root weight when plants are exposed to moderate light levels ( $10 \%$ to $35 \%$ of the solar radiation), followed by low light ( $<10 \%$ of the solar radiation) and then intensive light ( $>35 \%$ of the solar radiation). While this study offered important clues as to the adaptability of Asian ginseng to understory light, the effect of light on forest-grown american ginseng has not been studied.

Previous studies, however, showed that american ginseng growing under artificial shade attains a maximum photosynthetic rate when exposed to $200 \mu \mathrm{mol} \cdot \mathrm{m}^{-2} \cdot \mathrm{s}^{-1}$, below which there is an exponential rise in photosynthetic rate following increasing light levels (Proctor, 1980). Furthermore, Asian ginseng plants exposed to high light levels $\left(720 \mu \mathrm{mol} \cdot \mathrm{m}^{-2} \cdot \mathrm{s}^{-1}\right)$ suffer from photoinhibition of photosynthesis (Parmenter and Littlejohn, 1998, 2000; Smallfield et al., 1995), and if the conditions persist, there is a subsequent bleaching of chlorophyll pigments, followed by premature leaf death (Parmenter and Littlejohn, 2000; Proctor and Bailey, 1987). However, premature leaf death does not necessarily translate into reduced root weights since Asian ginseng plants exposed to 720 $\mu \mathrm{mol} \cdot \mathrm{m}^{-2} \cdot \mathrm{s}^{-1}$ have similar root weights than plants grown under 160 or $400 \mu \mathrm{mol} \cdot \mathrm{m}^{-2} \cdot \mathrm{s}^{-1}$ (Parmenter and Littlejohn, 2000).

The physiology and structure of developing plants are not only affected by incident light quantity but also light quality (Barker et al., 1997; Bukhov et al., 1995; González et al., 1998; Vladimirova et al., 1997). During forest canopy development, understory light quality changes due to the selective absorption of red (R) and blue (B) light by canopy leaves (Dalling et al., 1999; MacLellan and Frankland, 1985). Changes in R versus far red (FR) light ratios incident of plants affect phytochrome-mediated processes, and can profoundly affect plant growth and development (de la Rosa et al., 1999; Morgan and Smith, 1976; Stuefer and Huber, 1998; Tasker and Smith, 1977), while other species are hardly affected (Assman, 1992; Lee, 1985; Smith, 1982; Warrington et al., 1988). The effect of light quality on forest-grown american ginseng has not been studied. Our objective was to determine the relationship between understory light levels and light quality, including sunfleck durations, on growth and morphology of 1- and 2-year-old american ginseng plants cultivated in a forest.

\section{Materials and Methods}

Plant material and experimental Design. In Oct. 1998, stratified american ginseng seeds (Panax Q Farm Ltd., Vernon, $\mathrm{BC}$, Canada) were planted in 15 experimental units each measuring $6 \mathrm{~m}^{2}$ in a broadleaf forest at Île d'Orléans, Que., Canada (Lat. $46^{\circ} 57^{\prime} \mathrm{N}$; Long. $70^{\circ} 56^{\prime} \mathrm{W}$ ). Forest canopy trees, primarily composed of Fagus grandifolia, Acer saccharum, and Betula allenghaniensis, had a leaf area index ( $\mathrm{LAI} \pm \mathrm{SD})$, measured using hemispherical photography (see below for description), of 2.3 \pm 0.3 in September 1999 and $2.5 \pm 0.3$ in September 2000. The location of each experimental unit was allotted randomly on a forest surface area of 1.2 ha. Due to the heterogeneous nature of the forest canopy, there was no repetition of light levels, which were estimated at fixed points (one point per experimental unit) in each experimental unit. Before sowing ginseng seeds at a density of $30 \mathrm{~kg} \cdot \mathrm{ha}^{-1}$, the soil was tilled to a depth of $15 \mathrm{~cm}$ and lime was incorporated $\left(6 \mathrm{t} \cdot \mathrm{ha}^{-1}\right)$ to elevate soil $\mathrm{pH}$ to 5.2 . The experimental units contained $\approx 150$ ginseng plants per unit and weeding was done by hand weekly to minimize competition. Average soil mineral concentrations $(\mathrm{ppm} \pm \mathrm{SD})$ during 1999 and 2000 were $15 \pm 8$ $\mathrm{P}, 86 \pm 22 \mathrm{~K}, 3085 \pm 1062 \mathrm{Ca}, 50 \pm 10 \mathrm{Mg}, 1568 \pm 245 \mathrm{Al}, 258$ $\pm 34 \mathrm{Fe}, 2.0 \pm 0.8 \mathrm{Cu}, 10.3 \pm 6.9 \mathrm{Mn}, 20.24 \pm 7.48 \mathrm{Zn}, 0.17 \pm$ $0.04 \mathrm{~B}, 12 \% \pm 1 \%$ organic matter, and electrical conductivity of $0.114 \pm 0.028 \mathrm{dS} \cdot \mathrm{m}^{-1}$.

HEMISPHERICAL PHOTOGRAPHY. Using hemispherical photography (Beaudet and Messier, 2002; Frazer et al., 1999), total (direct plus diffuse), direct, and diffuse light photon flux density (PFD), and sunfleck durations were estimated in each experimental unit at fixed points in September 1999 and at regular intervals (total of 14 times) from May to September 2000. Previous studies have shown significant positive correlations between direct sensor measurements and indirect photographic estimates of light transmission with hemispheric photographs (Chazdon and Field, 1987; Easter and Spies, 1994; Gendron et al., 1998). Hemispherical photographs of the forest canopy were recorded skyward on overcast days with uniform cloud cover using a digital camera (CoolPix 800; Nikon Corp., Tokyo, Japan) equipped with a fisheye lens converter (FCE8; Nikon Corp.) assembled on a leveled tripod one meter above ground level. The images were then analyzed using a computer software named Gap Light Analyzer, version 2.0 (University of Victoria, B.C., Canada), which uses a solar radiation model that accounts for the influence of topography and seasonal patterns of cloudiness to estimate light levels. The physical location of the site (geographical location, slope, elevation), solar constant, cloudiness index, beam fraction (ratio of direct to total spectral radiation), and clear-sky transmission coefficient based on average North American conditions were parameters included in the program to account for atmospheric conditions during the growing seasons. Images were analyzed by transforming image pixel positions into angular coordinates, dividing pixel intensities into sky and nonsky classes (canopy foliage), and computing sky brightness distributions. The estimation of sunfleck durations using hemispherical photography does not take into consideration the movement of canopy leaves by the wind and the effect of clouds (Beaudet and Messier, 2002; Canham et al., 1990).

The software estimated mean daily PFD during a time period (start and end dates) which, in our case, was from the day after the previous recording session to the day photographs were recorded during the 2000 growing season. Cumulative PFD were calculated by adding mean daily PFD $\left(\mathrm{mol} \cdot \mathrm{m}^{-2} \cdot \mathrm{d}^{-1}\right)$ estimated from May to July 2000 for analyses in July 2000, and from May to September 2000 for analyses in September 2000. In 1999, mean daily PFD were estimated from July to September. However, cumulative PFD (May to September) were not determined in 1999 since light levels were not estimated during the development of the forest canopy (May to July). Diffuse light is atmospheric light energy dispersed by atmospheric particles and dust, while direct light is nondispersed atmospheric light (Frazer et al., 1999). Sunflecks are naturally found gaps in the forest canopy that allow the penetration of direct beam radiation to the forest understory (Frazer et al., 1999).

SPECTRORAdIOMETRY. Understory light quality (300 to 1100 $\mathrm{nm}$ ) was measured between 10:00 and 14:00 HR with a spectroradiometer (LI-1800; LI-COR, Inc., Lincoln, Neb.) by placing a sensor at a fixed point in the experimental units before (4 May 2000), during (28 May 2000), and after (4 July 2000) the development of the forest canopy. For each wavelength, three consecutive measurements were recorded and average values were subsequently used to determine ultraviolet (UV) (300 to $380 \mathrm{~nm})$, red (R) (655 to $665 \mathrm{~nm})$, far red (FR) (725 to $735 \mathrm{~nm})$, and R:FR ratio (de la Rosa et al., 1999). 
GROWTH AND MORPHOLOGY OF SHOOTS AND ROOTS. Nine (September 1999) and five (July and September 2000) american ginseng plants were randomly selected in each experimental unit to measure shoot and root growth, and morphology. Average values was calculated for each experimental unit and used in statistical analyses. Shoot and root fresh weights (FW) and dry weights (DW) were determined before and after a 48 -h drying period at $40^{\circ} \mathrm{C}$ (Charest et al., 2000). Third leaflet surface area was measured using a planimeter (LI-3000A; LI-COR). Fibrous root (diameter $\leq 1 \mathrm{~mm}$ ) and taproot (diameter $>1 \mathrm{~mm}$ ) areas were determined on fuchsin $(0.005 \%$ solution) stained roots using Win Rhizo, version 3.8a (Régent Instrument, Inc., Quebec, Que., Canada) (Lambany and Veilleux, 1999).

Statistical analysis was performed using the program named Essential Regression for Excel 97 (ER, 2.219). Using a linear and nonlinear (ln) models, and their two way interactions, multiple regression analysis was used to determine light factors that best modeled growth and morphology of american ginseng plants. For 1-year-old plants (1999), terms used in multiple regression model were mean daily total, direct, diffuse PFD, and sunfleck durations. For 2-year-old plants (July 2000), terms used in the model were daily and cumulative total, direct, and diffuse PFD, and sunfleck durations, and UV and R:FR fluence rates. For 2year-old plants (September 2000), terms used in the statistical model were daily and cumulative PFD (total, direct, diffuse, and sunfleck durations). Residual analyses for normal distribution were also done.

\section{Results}

Multiple regression analysis showed that shoot and root DW were best modeled by daily sunfleck durations, accounting for up to $56 \%$ of the variation (Fig. 1A and B). One-year-old american ginseng plants exposed to increasing sunfleck durations had decreasing shoot and root DW, especially when exposed to over $2 \mathrm{~h} \cdot \mathrm{d}^{-1}$ sunfleck durations (Fig. 1A and B). Further analyses were done using only data for plants exposed to $<2 \mathrm{~h} \cdot \mathrm{d}^{-1}$ sunfleck durations (11 experimental units), revealing that shoot and root DW of 1 -year-old american ginseng plants exposed to $<2 \mathrm{~h} \cdot \mathrm{d}^{-1}$ sunflecks were positively related to the interaction between daily diffuse and total PFD, accounting for up to $69 \%$ of the variation (Fig. $2 \mathrm{~A}$ and $\mathrm{B}$ ). Furthermore, fibrous root (diameter $\leq 1 \mathrm{~mm}$ ) area of 1 -year-old plants was positively related to the interaction between daily total PFD and sunfleck durations (Fig. 3A), while taproot area (diameter $>1 \mathrm{~mm}$ ) was best modeled by sunfleck durations, accounting for $47 \%$ of the variation (Fig. 3B). Root DW of 2year-old plants collected in September 2000 was related to cumulative diffuse PFD, accounting for $45 \%$ of the variation (Fig. 4). However, root morphology of 2-year-old plants collected in September 2000 was not related to understory light $(P>0.05)$ (data not presented). Two-year-old american ginseng plants were exposed to lower average sunfleck durations in July to September 2000 compared to 1-year-old plants (1999) during the same period with 1.5 to $1.8 \mathrm{~h} \cdot \mathrm{d}^{-1}$ sunfleck durations, respectively (Fig. 5). However, mean daily total, direct, and diffuse PFD decreased only slightly from 1999 to 2000 (Fig. 5).

During the 2000 growing season, understory daily total, direct, and diffuse PFD, and sunfleck durations decreased from mid-May to end of May with only moderate variations thereafter (Fig. 6). Notably, after the month of May, average sunfleck durations lasted $<2 \mathrm{~h} \cdot \mathrm{d}^{-1}$ (Fig. 6). Understory UV, R, and FR fluence rates, and $\mathrm{R}: \mathrm{FR}$ ratio also declined during the development of the forest canopy, from 4 May (before canopy development) to 28 May (during canopy development) to 4 July 2000 (after canopy development) (Fig. 7).

In July 2000, shoot DW was positively linearly related to cumulative diffuse PFD and to the added effect of UV light (4 July 2000) and daily total PFD (Fig. 8A). Root FW was also positively linearly related to cumulative diffuse PFD, and to the interaction between UV light (4 July 2000) and cumulative sunfleck durations (Fig. 8B) (root DW was not determined in July 2000). While leaflet area and stem length of 1-year-old plants were not related to understory light levels $(P>0.05)$ (data not presented), leaflet area of 2-year-old american ginseng plants measured in July 2000 was positively linearly related to interaction between UV light (4 July 2000) and cumulative diffuse PFD, and UV light (28 May 2000) and cumulative diffuse PFD (Fig. $8 \mathrm{C})$. Moreover, root FW and leaflet area were negatively correlated with the interactive effect between R:FR (28 May 2000) and daily diffuse PFD (root FW) (Fig. 8B), and UV light (4 July 2000) (leaflet area) (Fig. 8C).

\section{Discussion}

The heterogeneous nature of the forest canopy creates a mosaic of light in the understory that significantly affects growth and morphology of 1- and 2-year-old american ginseng. The results showed that daily sunfleck durations best modeled shoot and
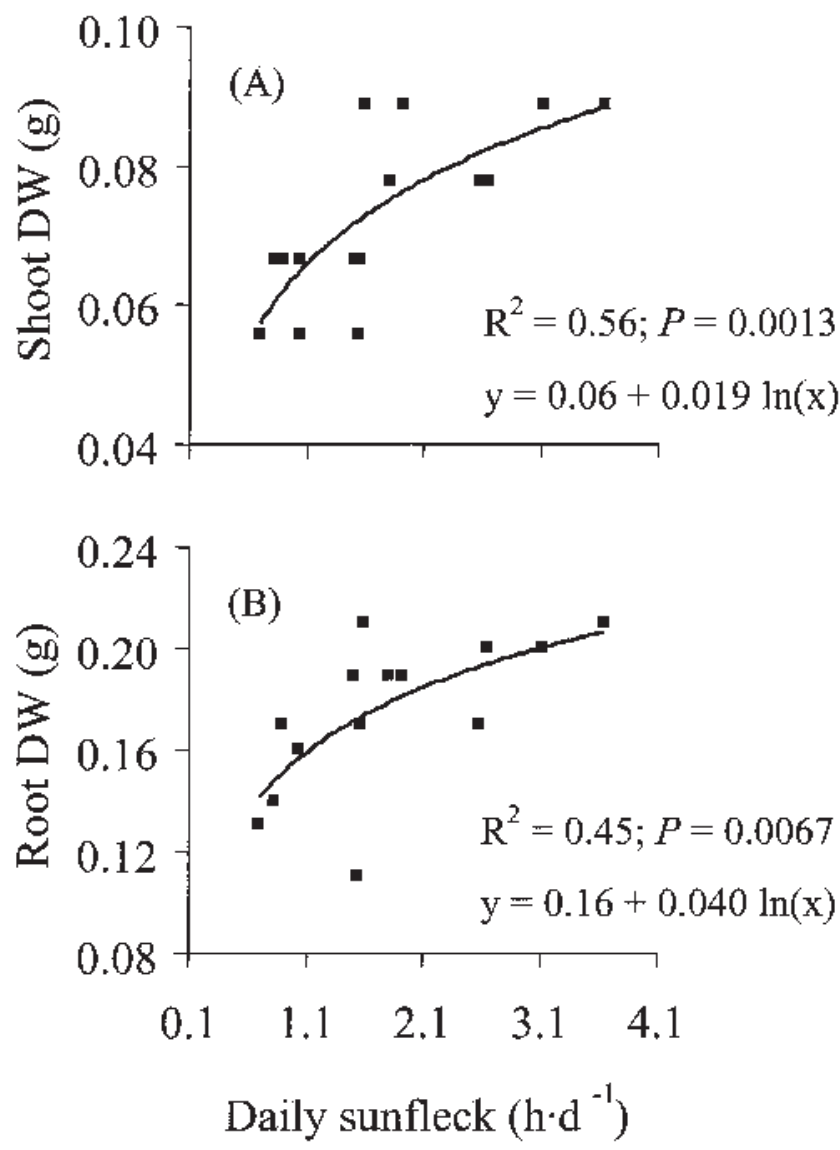

Fig. 1. Relationship between mean daily sunfleck durations (July to September 1999) and dry weight (DW) of 1-year-old (A) shoots and (B) roots of american ginseng collected in September 1999 in a broadleaf forest. Multiple regression was performed using data collected in 15 experimental units (9 samples per unit). 

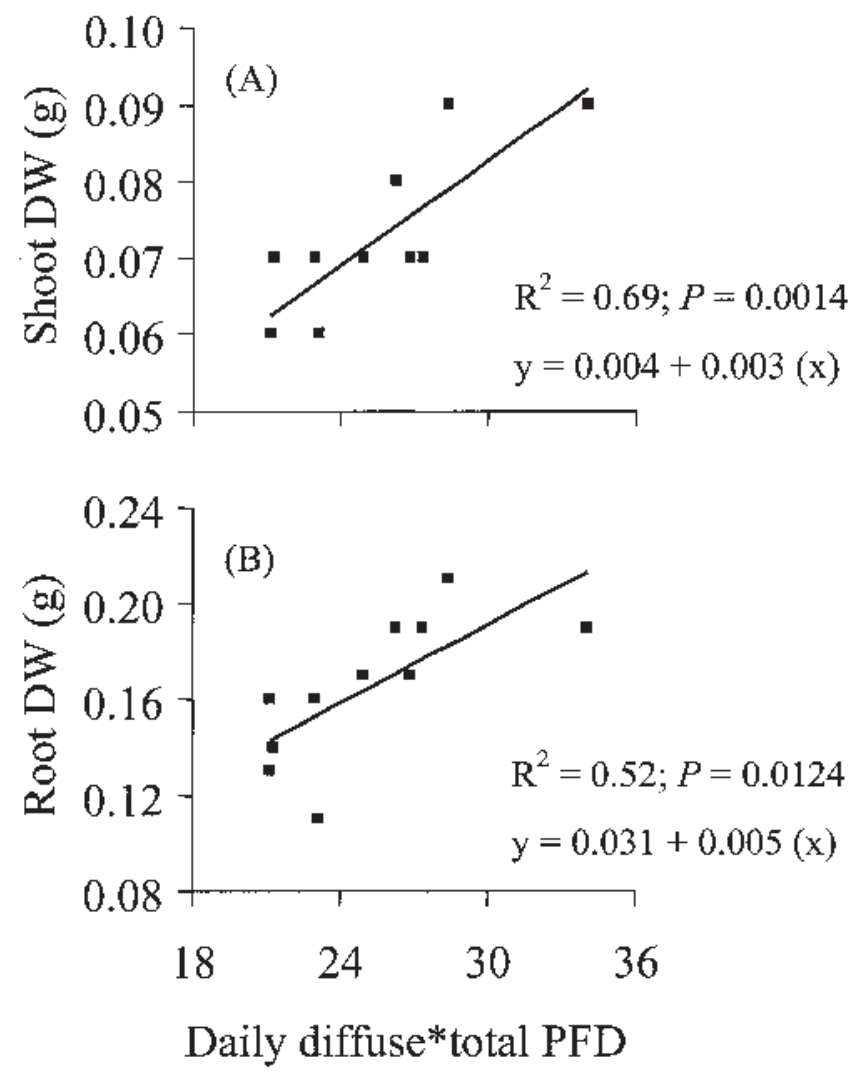

Fig. 2. Relationship between the interaction of mean daily diffuse and total PFD, and (A) shoot and (B) root dry weight (DW) of 1-year-old american ginseng exposed to $<2 \mathrm{~h} \cdot \mathrm{d}^{-1}$ sunfleck durations in a broadleaf forest. Multiple regression was performed using data collected in 11 experimental units (9 samples per unit).

root DW (Fig. 1A and B), and taproot area (Fig. 3B) of 1-yearold american ginseng plants, accounting for up to $56 \%$ of the variation. However, the relationship reached a plateau at $\approx 2 \mathrm{~h} \cdot \mathrm{d}^{-1}$ sunfleck durations when plants exposed to the highest sunfleck durations $\left(>2 \mathrm{~h} \cdot \mathrm{d}^{-1}\right)$ suffered from reduced growth (Fig. 1A-B) probably because direct PFD transmitted through gaps was over their point of light saturation. While light energy transmitted through gaps can represent $40 \%$ to $80 \%$ of understory light (Pfitsch and Pearcy, 1989; Valladares and Pearcy, 1998), its utilization can account for only $20 \%$ to $40 \%$ of $\mathrm{CO}_{2}$ assimilation in certain shade plants (Valladares and Pearcy, 1998). Photosynthesis of american ginseng plants could have been further restricted by long sunflecks because of increased leaf temperatures and higher water losses. However, 1-year-old plants exposed to longer sunflecks had increased fibrous root areas (Fig. 3A) which probably contributed to increasing uptake of mineral elements and water (Haase and Rose, 1994), compensating for potential losses. Even if american ginseng is a shade plant, it was capable of effectively using direct sunlight transmitted through forest gaps probably by developing physiological mechanisms to absorb understory light such as thicker leaves, larger mesophyll surface areas, and higher numbers of mesophyll cells, as was previously shown in Asian ginseng (Zhang et al., 1995).

The data further showed that 1 -year-old american ginseng plants exposed to sunfleck durations $<2 \mathrm{~h} \cdot \mathrm{d}^{-1}$ were correlated with daily diffuse and total PFD, accounting for up to $69 \%$ of the variation (Fig. 2A and B), implying that light was a major controlling factor of growth at lower sunfleck durations. Similarly, shoot DW and root FW measured in July 2000, and root DW measured in

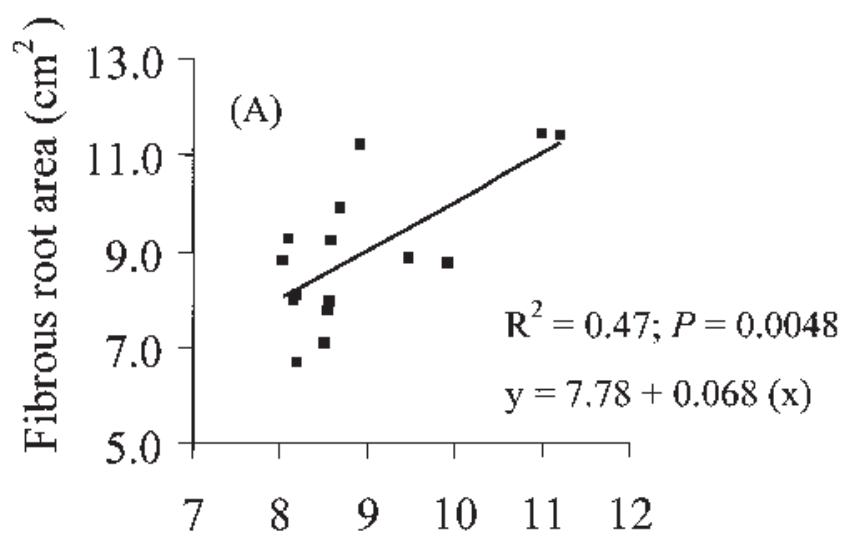

\section{Daily total PFD*sunfleck}

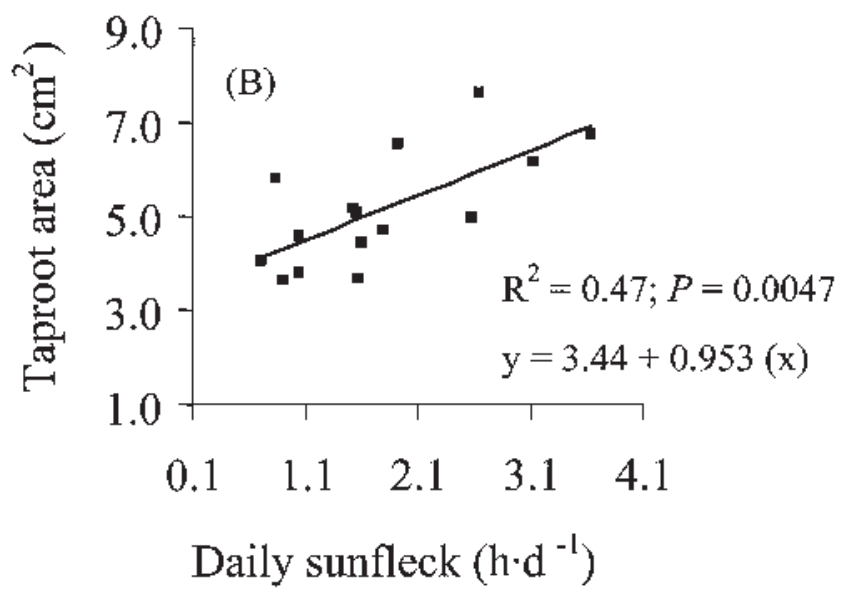

Fig. 3. Relationship between the interaction of mean daily total PFD and sunfleck durations, and (A) fibrous root area, and daily sunfleck durations and (B) taproot area of 1-year-old american ginseng plants collected in September 1999 in a broadleaf forest. Multiple regression was performed using data collected in 15 experimental units (5 samples per unit).

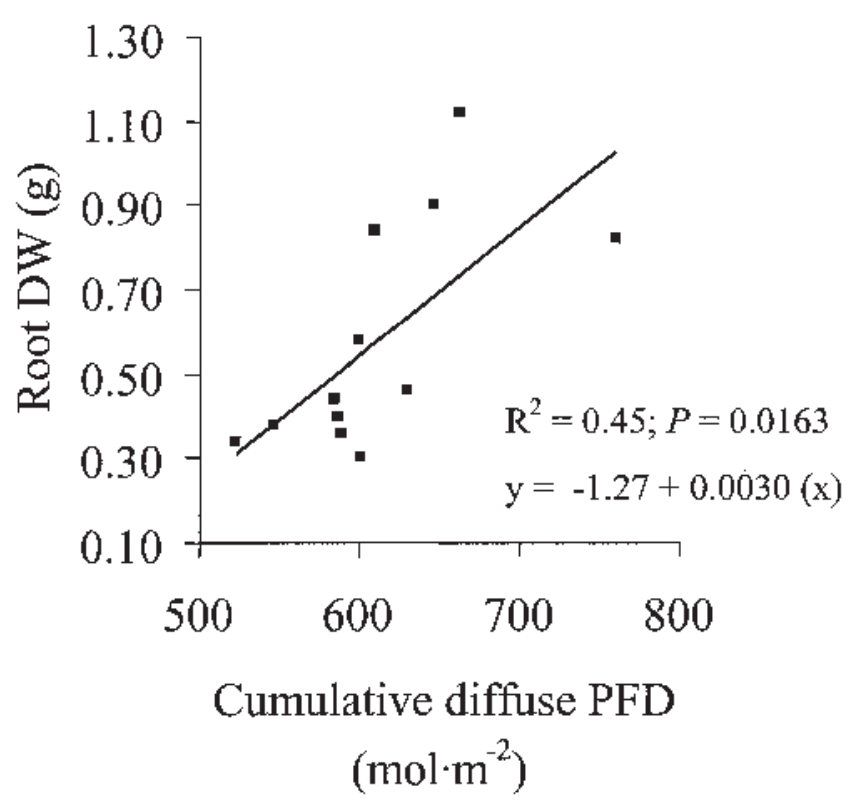

Fig. 4. Relationship between cumulative diffuse PFD and root dry weight (DW) of 2-year-old american ginseng plants collected in September 2000 in a broadleaf forest. Multiple regression was performed using data collected in 12 experimental units (5 samples per unit). 


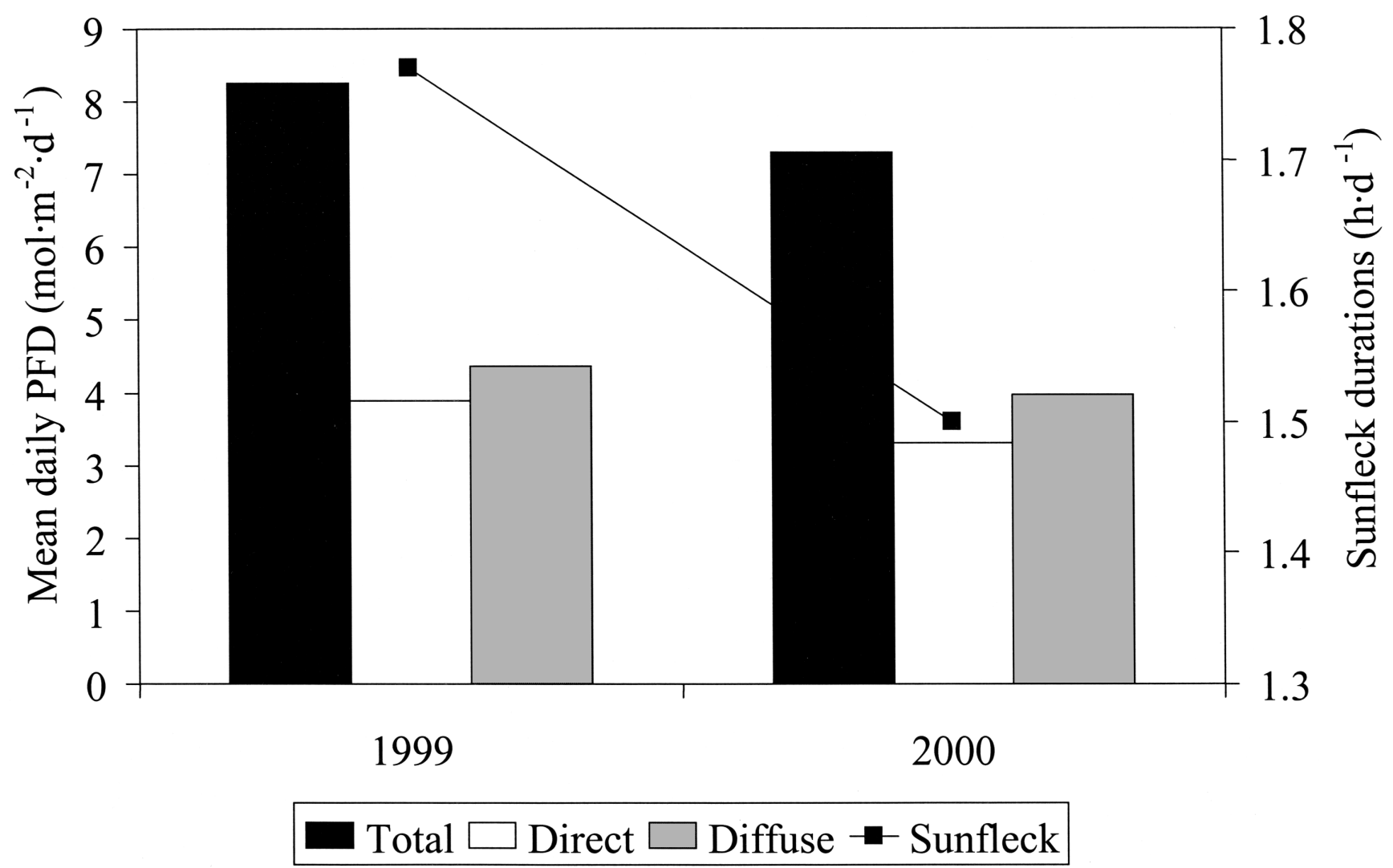

Fig. 5. Variation of mean daily total, direct, and diffuse PFD, and sunfleck durations (from July to September) in a forest understory in 1999 and 2000 . Data are mean values of 15 (1999) and 75 (2000) independent measurements.

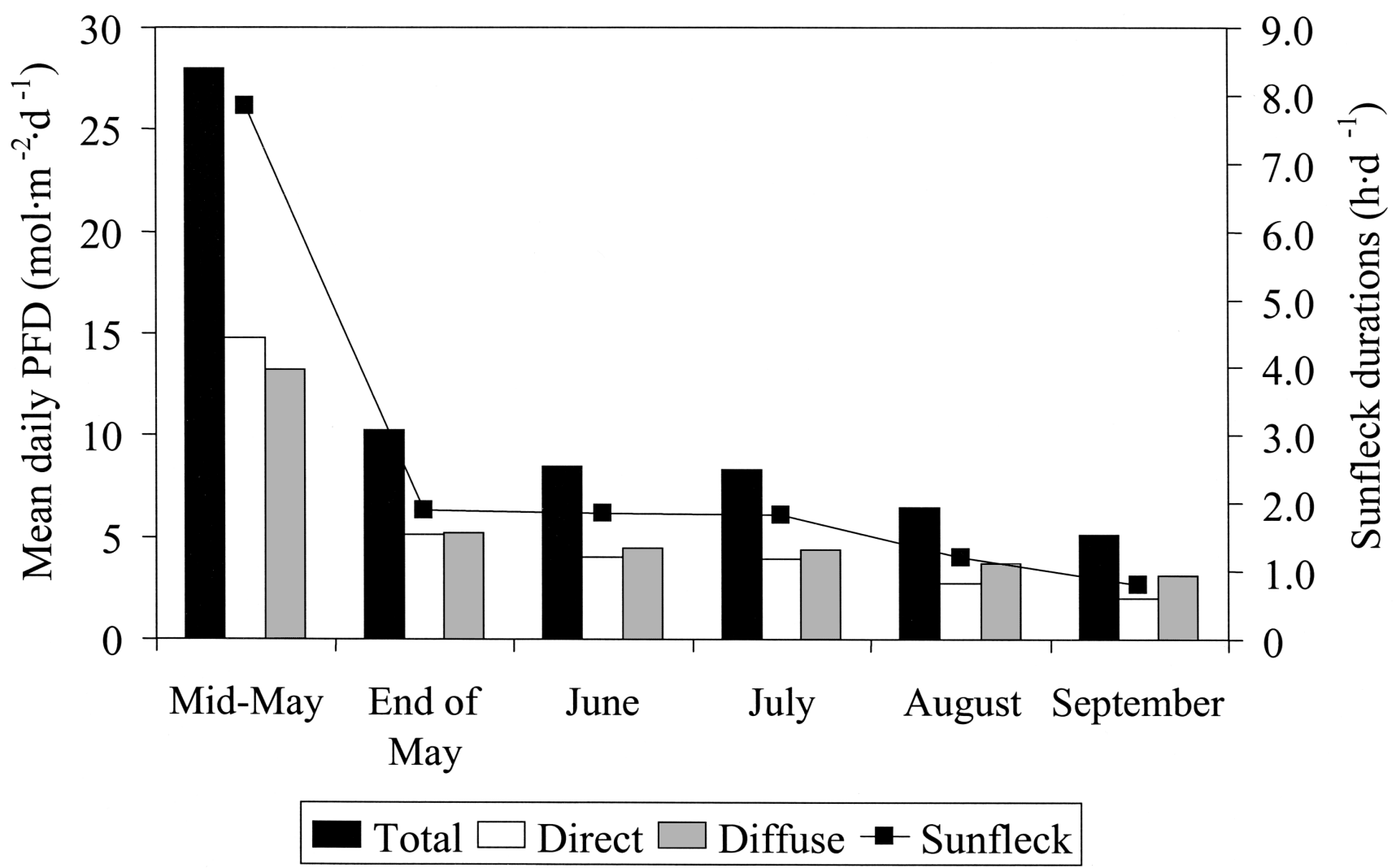

Fig. 6. Seasonal variation of mean daily total, direct, and diffuse PFD, and sunfleck durations from mid-May to September 2000 in the understory of a broadleaf forest. Data are mean values of 15 to 135 independent measurements. 


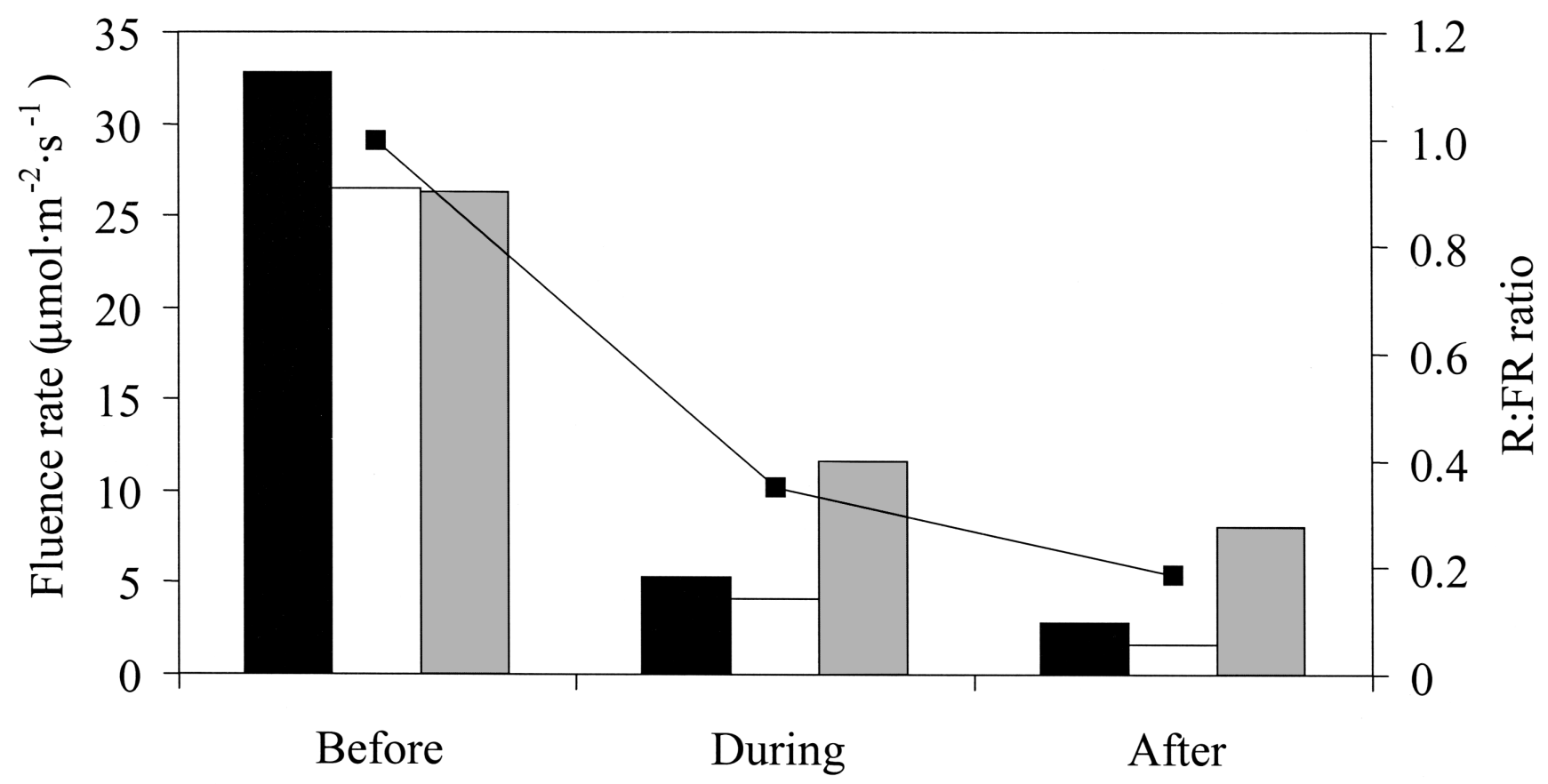

canopy development

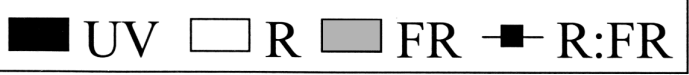

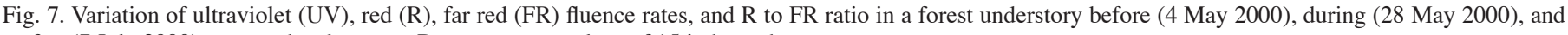
after (7 July 2000) canopy development. Data are mean values of 15 independent measurements.

September 2000 of 2-year-old american ginseng plants were also correlated with cumulative diffuse PFD, accounting for up to $45 \%$ of the variation (Fig. 4). Two-year-old american ginseng plants were generally exposed to shorter sunflecks than 1-year-old plants (Fig. 5), with an average of $1.5 \mathrm{~h} \cdot \mathrm{d}^{-1}$ compared to $1.8 \mathrm{~h} \cdot \mathrm{d}^{-1}$ for 1999, which decreased the potential for light saturation. Previous studies showed that shade plants (Sims and Pearcy, 1993; Valladares and Pearcy, 1998) preferentially use diffuse light rather than direct light for carbon gain with up to nine times higher growth than those grown under short or long sunflecks. One- and 2-year-old american ginseng plants probably used diffuse PFD at maximum quantum yield for $\mathrm{CO}_{2}$ assimilation since its PFD (4.4 $\mathrm{mol} \cdot \mathrm{m}^{-2} \cdot \mathrm{d}^{-1}$ in 1999 and $4.0 \mathrm{~mol} \cdot \mathrm{m}^{-2} \cdot \mathrm{d}^{-1}$ in 2000) (Fig. 5) was well below their point of light saturation established at $200 \mu \mathrm{mol} \cdot \mathrm{m}^{-2} \cdot \mathrm{s}^{-1}$ (Proctor, 1980). Hence, higher growth rates would probably be obtained by exposing american ginseng plants to between 100 to $200 \mu \mathrm{mol} \cdot \mathrm{m}^{-2} \cdot \mathrm{s}^{-1}$ diffuse PFD since the results showed linear relationships between diffuse PFD and growth.

The development of the forest canopy altered light PFD (Fig. 6) and light quality (Fig. 7) in the understory. In mid-May 2000, young 2-year-old american ginseng plants were exposed to sunflecks lasting on average $8 \mathrm{~h} \cdot \mathrm{d}^{-1}$ and total PFD averaging $28 \mathrm{~mol} \cdot \mathrm{m}^{-2} \cdot \mathrm{d}^{-1}$ (Fig. 6), which could have caused inhibition of photosynthesis (Proctor, 1980) and stunted growth. However, american ginseng was only exposed to these high PFD and long sunfleck durations during its initial leaf development. The rapid development of the forest canopy decreased light PFD by $64 \%$ to levels below saturating PFD for american ginseng plants (Proctor, 1980). Similarly, UV and R:FR ratio decreased following canopy development. Notably, average UV fluence rate decreased by $91 \%$ and average R:FR ratio decreased from 1.0 to 0.2 during canopy development (Fig. 7).

At the end of canopy development (July 2000), shoot and root growth, in addition to leaflet area, were positively related to cumulative diffuse PFD, while higher R:FR ratio stunted leaflet area and root growth of 2-year-old american ginseng (Fig. 8A-C). Since R light was largely absorbed by forest canopy leaves (Dalling et al., 1999; MacLellan and Frankland, 1985), american ginseng in the forest understory was gradually exposed to reduced R:FR ratios (Fig. 7) that could have induced a phytochrome-mediated response involved in the perception of shade (de la Rosa et al., 1999; Morgan and Smith, 1976; Smith, 1982; Stuefer and Huber, 1998; Tasker and Smith, 1977). In this sense, lower R:FR ratio in diffuse radiation compared to direct radiation (Lee, 1987) could in part account for the positive influence of diffuse light on shoot and root growth of american ginseng plants. Light quantity and light quality both influenced the allocation of biomass to increasing assimilatory tissue (leaf area), concordant with results obtained in sun plants grown in shade (Stuefer and Huber, 1998), but not with results generally observed in shade plants (Assmann, 1992; Lee, 1985; Smith, 1982; Warrington et al., 1988). While american ginseng is identified as an obligate shade plant (Hsu, 2002), the results suggest that it has physiological responses resembling facultative shade plants. Moreover, Proctor (1980) showed that chlorophyll $\mathrm{a} / \mathrm{b}$ ratio of american ginseng plants grown under artificial shade is comparable to sun species, with a 3:1 ratio.

Leaflet area of 2-year-old plants (July 2000) was also positively related to UV fluence rates during and after the development of the forest canopy (Fig. 8C). Understory plants exposed to higher UV light have been shown to suffer from DNA damage through 

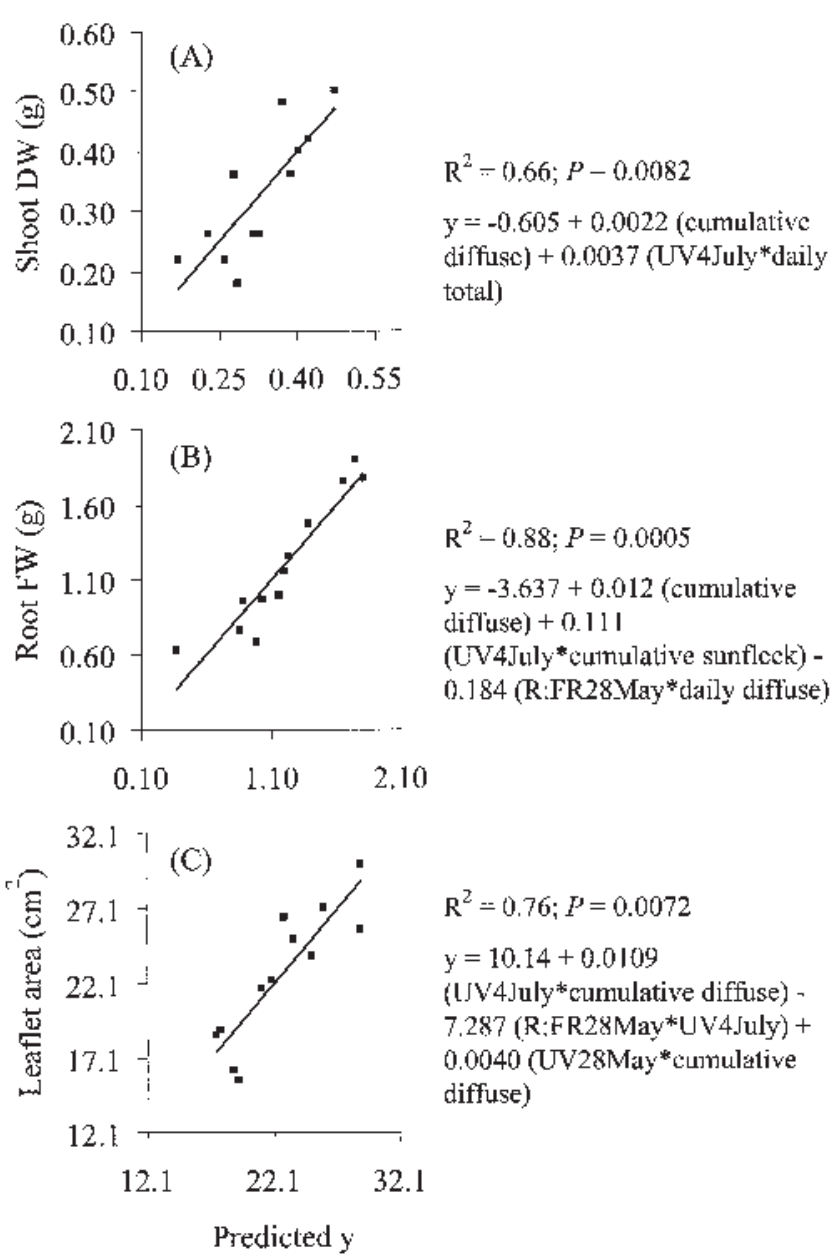

Fig. 8. Relationship between daily and cumulative light PFD, and light quality [ultraviolet (UV) and red to far red (R:FR) ratio], and (A) shoot dry weight (DW) and (B) root fresh weight (FW), and (C) leaflet area of 2-year-old american ginseng plants collected in July 2000 in a broadleaf forest. Multiple regression was performed using data collected in 12 experimental units (5 samples per unit).

the formation of DNA dimers (Taylor et al., 1997) and reduced biomass (Allen et al., 1998). However, 2-year-old american ginseng plants had higher growth and increased leaflet areas when exposed to higher UV light. González et al. (1998) showed that plants exposed to high followed by low UV-B levels, as was the case in our study (Fig. 7) caused by canopy development, have higher leaf areas than those exposed to consistently high or low UV-B levels. The allocation of more carbon energy to leaves, which are critical to future plant productivity (Parmenter and Littlejohn, 1998; Sinha, 1999), probably accounted for the higher shoot weight since stem length was not influenced by light quantity or light quality, as previously shown for other shade plants (Assmann, 1992; Lee, 1985; Smith, 1982).

In summary, the results showed that growth and morphology of 1-year-old american ginseng plants were related to daily sunfleck durations, but the relationship reached a plateau at $\approx 2 \mathrm{~h} \cdot \mathrm{d}^{-1}$ sunfleck durations for growth. Exposed to $<2 \mathrm{~h} \cdot \mathrm{d}^{-1}$ sunfleck durations, growth of 1-year-old plants was correlated with diffuse and total PFD. In July, growth and morphology of 2-year-old american ginseng plants were correlated with light PFD and light quality, specifically UV and R:FR ratio, accounting for up to $88 \%$ of the variation. Similarly, growth of 2-year-old american ginseng estimated in September was correlated with cumulative diffuse PFD. The data suggest that exposing american ginseng plants to higher diffuse PFD (up to $200 \mu \mathrm{mol} \cdot \mathrm{m}^{-2} \cdot \mathrm{s}^{-1}$ ) and $<2 \mathrm{~h} \cdot \mathrm{d}^{-1}$ sunfleck durations would maximize root growth. Sims and Pearcy (1993) suggested that if PFD supplied in sunflecks could be more uniformly distributed, by growing understory plants under tall canopies with small leaves (Smith et al., 1989) for example, then growth of understory plants could be maximized. Small gap diameters produce penumbral sunflecks that contain higher proportions of diffuse light than larger gaps (Chazdon and Pearcy, 1991), hence increasing diffuse PFD in the understory.

\section{Literature Cited}

Allen, D.J., S. Nogués, and N.R. Baker. 1998. Ozone depletion and increased UV-B radiation: Is there a real threat to photosynthesis? J. Expt. Bot. 49:1775-1788.

Anderson, R.C., J.S. Fralish, and J.E. Armstrong. 1993. The ecology and biology of Panax quinquefolium L. (Araliaceae) in Illinois. Amer. Midl. Nat. 129:357-372.

Assmann, S.M. 1992. Effects of light quantity and quality during development on the morphology and stomatal physiology of Commelina communis. Oecologia 92:188-195.

Barker, D.H., G.G.R. Seaton, and S.A. Robinson. 1997. Internal and external photoprotection in developing leaves of the CAM plant Cotyledon orbiculata. Plant Cell Environ. 20:617-624.

Beaudet, M. and C. Messier. 2002. Variation in canopy openness and light transmission following selection cutting in northern hardwood stands: an assessment based on hemispherical photographs. Agr. For. Meteorol. 110:217-228.

Betz, J.M., A.H. Der Marderosian, and T.M. Lee. 1984. Continuing studies on the ginsenoside content of commercial ginseng products by TLC and HPLC, II, p. 65-83. In: J.T.A. Proctor (ed.). Proc. 6th N. Amer. Ginseng Conf., Guelph Univ., Ont.

Briskin, D.P. 2000. Medicinal plants and phytomedicines: linking plant biochemistry and physiology to human health. Plant Physiol. 124: 507-514.

Bukhov, N.G., I.S. Drozdova, and V.V. Bondar. 1995. Light response curves of photosynthesis in leaves of sun-type and shade-type plants grown in blue or red light. Photochem. Photobiol. 30:39-41.

Canham, C.D., J.S. Denslow, W.J. Platt, J.R. Runkle, T.A. Spies, and P.S. White. 1990. Light regimes beneath closed canopies and tree-fall gaps in temperate and tropical forests. Can. J. For. Res. 20:620-631.

Charest, P., L. Gauthier, S. Khanizadeh, and M. Dorais. 2000. The influence of soil preparation, seedling rates and organic mulch on the production of woods-cultivated ginseng. Acta Hort. 523:87-96.

Charron, D. and D. Gagnon. 1991. The demography of northern populations of Panax quinquefolium (american ginseng). J. Ecol. 79(2): 431-445.

Chazdon, R.L. and C.B. Field. 1987. Photographic estimation of photosynthetically active radiation: evaluation of a computerized technique. Oecologia 73:525-532.

Chazdon, R.L. and R.W. Pearcy. 1991. The importance of sunflecks for forest understory plants. BioScience 41(11):760-766.

Court, W.A., L.B. Reynolds, and J.G. Hendel. 1996. Influence of root age on the concentration of ginsenosides of american ginseng (Panax quinquefolium). Can. J. Plant Sci. 76:853-855.

Dalling, J.W., C.E. Lovelock, and S.P. Hubbell. 1999. Growth responses of seedlings of two neotropical pioneer species to simulated forest gap environments. J. Trop. Ecol. 15:827-839.

de la Rosa, T.M., T. Lehto, and P.J. Aphalo. 1999. Does far-red light affect growth and mycorrhizas of scots pine seedlings grown in forest soil? Plant Soil 211:259-268.

Easter, M.J. and T.A. Spies. 1994. Using hemispherical photography for estimating photosynthetic photon flux density under canopies and in 
gaps in douglas-fir forests of the Pacific Northwest. Can. J. For. Res. 24:2050-2058.

Fournier, A.R., J.T.A. Proctor, L. Gauthier, S. Khanizadeh, A. Bélanger, A. Gosselin, and M. Dorais. 2003. Understory light and root ginsenosides in forest-grown Panax quinquefolius. Phytochemistry 63(7): 777-782.

Frazer, G.W., C.D. Canham, and K.P. Lertzman. 1999. Gap Light Analyser (GLA): Imaging software to extract canopy structure and gap light transmission indices from true-colour fisheye photographs, users manual and program documentation. Simon Fraser Univ., Burnaby, B.C., and the Inst. Ecosystem Studies, Millbrook, N.Y.

Gendron, F., C. Messier, and P.G. Comeau. 1998. Comparison of various methods for estimating the mean growing season percent photosynthetic photon flux density in forests. Agr. For. Meteorol. 92:55-70.

González, R., R. Mepsted, A.R. Wellburn, and N.D. Paul. 1998. Nonphotosynthetic mechanisms of growth reduction in pea (Pisum sativum L.) exposed to UV-B radiation. Plant Cell Environ. 21:23-32.

Haase, D.L. and R. Rose. 1994. Effect of soil water content and initial root volume on the nutrient status of $2+0$ douglas fir seedlings. New Forests 8:265-277.

Hsu, P.C. 2002. Commercial production of american ginseng (Panax quinquefolius L.). Native Plants J. 3(2):106-108.

Königer, M., G.C. Harris, A. Virgo, and K. Winter. 1995. Xanthophyllcycle pigments and photosynthetic capacity in tropical forest species: A comparative field study on canopy, gap and understory plants. Oecologia 104:280-290.

Kursar, T.A. and P.D. Coley. 1999. Contrasting modes of light acclimation in two species of the rainforest understory. Oecologia 121:489-498.

Lambany, G. and L. Veilleux. 1999. Système d'imagerie informatisée appliqué au développement des racines de semis d'épinette. For. Res. Notes n ${ }^{\circ} 97$. Que. Govt., Ministry Natural Resources, Que.

Lee, D.W. 1985. Duplicating forest shade for research on plant development. HortScience 20:116-118.

Lee, D.W. 1987. The spectral distribution of radiation in two neotropical rain forests. Biotropica 19:161-166.

MacLellan, A.J. and B. Frankland. 1985. A simple field method for measuring light quality: seasonal changes in a temperate deciduous wood. Photochem. Photobiol. 42:689-695.

Morgan, D.C. and H. Smith. 1976. Linear relationship between phytochrome photoequilibrium and growth in plants under simulated natural radiation. Nature 262:210-212.

Parmenter, G. and R. Littlejohn. 1998. The effect of irradiance during leaf development on photoinhibition in Panax ginseng C.A. Meyer. J. Ginseng Res. 22:102-113.

Parmenter, G. and R. Littlejohn. 2000. Effect of shade on growth and photosynthesis of Panax ginseng. New Zealand J. Crop Hort. Sci. 28: 255-269.

Persons, W.S. 1995. American ginseng farming in its native woodland habitat, p. 78-88. In: W.G. Bailey, C. Whitehead, J.T.A. Proctor, and J.T. Kyle (eds.). Proc. Intl. Ginseng Conf., Simon Fraser Univ. Press, B.C. Pfitsch, W.A. and R.W. Pearcy. 1989. Daily carbon gain by Adenocaulon bicolor (Asteraceae), a redwood forest understory herb, in relation to its environment. Oecologia 80:465-470.

Proctor, J.T.A. 1980. Some aspects of the Canadian culture of ginseng (Panax quinquefolius L.), particularly the growing environment, $\mathrm{p}$. 39-47. In: Y.C. Kim (ed.). Proc. 3rd Intl. Ginseng Symp., Korean Ginseng Res. Inst., Seoul.

Proctor, J.T.A. and W.G. Bailey. 1987. Ginseng: Industry, botany and culture. Hort. Rev. 9:187-236.

Proctor, J.T.A., D. Louttit, and J. Jiao. 1998. Seasonal growth and root respiration of North American ginseng. J. Ginseng Res. 22:161-167.

Sims, D.A. and R.W. Pearcy. 1993. Sunfleck frequency and duration affects growth rate of the understorey plant, Alocasia macrorrhiza. Funct. Ecol. 7:683-689.

Sinha, N. 1999. Leaf development in angiosperms. Annu. Rev. Plant Physiol. 50:419-446.

Smallfield, B.M., J.M. Follett, M.H. Douglas, J.A. Douglas, and G.A. Parmenter. 1995. Production of Panax spp. in New Zealand. Acta Hort. 390:83-89.

Smith, H. 1982. Light quality, photoperception, and plant strategy. Annu. Rev. Plant Physiol. 33:481-518.

Smith, W.K.,A.K. Knapp, and W.A. Reiners. 1989. Penumbral effects on sunlight penetration in plant communities. Ecology 70:1603-1609.

Stuefer, J.F. and H. Huber. 1998. Differential effects of light quantity and spectral light quality on growth, morphology and development of two stoloniferous Potentilla species. Oecologia 117:1-8.

Tasker, R. and H. Smith. 1977. The function of phytochrome in the natural environment. V. Seasonal changes in radiant energy quality in woodlands. Photochem. Photobiol. 26:487-491.

Taylor, R.M., A.K. Tobin, and C.M. Bray. 1997. DNA damage and repair in plants, p. 53-76. In: P.L. Lumsden (ed.). Plants and UV-B: Responses to environmental change. Univ. Press, Cambridge.

Valladares, F. and R.W. Pearcy. 1998. The functional ecology of shoot architecture in sun and shade plants of Heteromeles arbutifolia M. Roem., a Californian chaparral shrub. Oecologia 114:1-10.

Vladimirova, S.V., D.B. McConnell, and M.E. Kane. 1997. Morphological plasticity of Dracaena sanderana 'Ribbon' in response to four light intensities. HortScience 32:1049-1052.

Wang, H., J. Fan, X. Yang, G. Fan, Q. Liou, and H. Dai. 1995. A study on ginseng cultivation under forest conditions and its physiological and ecological characteristics, p. 452-462. In: W.G. Bailey, C. Whitehead, J.T.A. Proctor, and J.T. Kyle (eds.). Proc. Intl. Ginseng Conf., Simon Fraser Univ. Press, B.C.

Warrington, I.J., D.A. Rook, D.C. Morgan, and H.L. Turnbull. 1988. The influence of simulated shadelight and daylight on growth, development and photosynthesis of Pinus radiata, Agathis australis and Dacryduim cupressinum. Plant Cell Environ. 11:343-356.

Zhang, Z.A., K.Z. Xu, C.G. Quiao, Y.Y. Yin, X. Chen, and R.T. Quiao. 1995. The effects of light on the microstructure and ultrastructure of Panax ginseng leaves, p. 504-509. In: W.G. Bailey, C. Whitehead, J.T.A. Proctor, and J.T. Kyle (eds.). Proc. Intl. Ginseng Conf., Simon Fraser Univ. Press, B.C. 